\title{
Planning for freedom: From human capital to human capabilities
}

\section{Lesley Powell}

Chair Youth Unemployment, Employability and Empowerment, Nelson Mandela University, Gqerbeha, South Africa

lesleyjpowell@gmail.com

https://orcid.org/ 0000-0003-3886-2872

(Received: 13 July 2021; accepted: 12 October 2020)

\section{Abstract}

In this article, I build on critiques of the dominant skills orthodoxies that underpin National Skills Planning Systems (NSPS). I respond to calls for a broader conceptualisation of skills planning by discussing the contribution that the capability approach brings to the reconceptualisation of the role, purpose, and orientation of NSPS. Applying the capability approach as a thinking tool for building a broader approach to skills planning led to the identification of seven dimensions that frame an emancipatory approach to skills planning. My core argument is that COVID-19 has laid bare the urgent need for new approaches to skills planning that are informed by a different set of assumptions, driven by a different set of indicators, inclusive of different voices, undertaken through different processes, and, importantly, driven by a different set of goals. Responding to the call for a broader approach to skills planning and taking seriously the seven dimensions of an emancipatory skills planning system will require an alternative vision not only of skills and of work, but of society as a whole.

Keywords: skills planning, capability approach, human development, supply and demand

\section{Introduction}

There can be little disagreement that "a fundamental shift is taking place in the way we think about the future of work and its relationship to education, training and the labour market" (Brown, 2020, p. 491). National Skills Planning Systems (NSPS) is a central and enormously expensive public instrument that aims to monitor and respond to shifts in the supply and demand of skills. Framed within what Brown et al. (2020, p. 227) aptly termed "orthodox human capital and its links to neoliberal economics", NSPS attempts to identify what might be called the right education that aligns with the needs of employers and that increases production, profits, and economic growth. Although structures like NSPS differ across countries, what is common is the desire to "strengthen the diagnostic capacity of the state to 
identify skills imbalances" in the formal labour market (Rasool, 2016, p. 2) so that education and training can be aligned to better respond (Brown, 2020).

There is a large and growing body of literature that critiques the underpinning logics of NSPS (see, for example, Allais et al., 2021; Balwanz \& Ngcwangu, 2016; Cooper et al., 2019; Fataar, 2010; McGrath, 2012; McGrath et al., 2020; Powell \& McGrath, 2019a; Vally \& Motala, 2014; Wedekind, 2014 and many others). Critical of the human capital underpinnings of NSPS (Vally \& Motala, 2014) and sympathetic to the call for the "death of human capital" (Brown et al., 2020, p. 2), this literature acknowledges the realities of the job-scarce labour market (Brown et al., 2020; Thurow, 1972;), recognises the limitations of narrow notions of employability (Powell \& McGrath, 2019a), contests the instrumentality of supply and demand (Allais, et al., 2021; Balwanz \& Ngcwangu, 2016) and rejects the narrow ontology of the human that underpins the dominant skills orthodoxy (Bonvin, 2019; McGrath et al., 2020; Powell \& McGrath, 2014). In this article, I build on these critiques by responding to recent calls for a "broader conceptualization" of skills planning (Balwanz \& Ngcwangu, 2016, p. 42) that gives "weight to a broader range of capabilities and human motivations" (Brown et al., 2020, p. 143).

I do this by discussing the contribution that the capability approach brings to the reconceptualization of the role, purpose, and orientation of NSPS. In opposition to the dominant skills orthodoxy, the capability approach emphasises a broader role for skills development that includes the role that skills might play in employability but expands on this to include the importance of skills serving the public good through expanding human development and addressing complex social challenges (Powell \& McGrath, 2019a). The capability approach does this by insisting that the flourishing and wellbeing of people-rather than economic growth, firm productivity, or profits-be the central concern of development. In contrast to instrumental framings, skills in the capability approach are understood as valuable not only for accessing and participating in work, but also for cultivating the agency required for individuals and groups to "rethink their reality in and out of work, modify it, and make it more suitable to their desired development scenario" (Szekely, 2019, p. 413).

COVID-19 further highlighted the urgency of engaging with NSPS by exacerbating complex social problems and "la[ying] bare the deep inequalities" (Stiglitz, 2020, para. 1) that exist. This has led to arguments that any chance of building back better will need a "comprehensive rewriting of the rules of the economy" (Stiglitz, 2020, para. 6). There are four aspects that COVID-19 has laid bare that insist on this "comprehensive rewriting" (Stiglitz, 2020, para. 6) of the rules of the economy and, with that, the rewriting of the purposes of skills development and skills planning.

The first is that it has highlighted the need to strengthen community medical services and the local production and distribution of essential products such as medical supplies and food. The shutting down of national borders emphasised the fragility of global distribution chains and the social injustice of monopolistic pharmaceutical companies limiting the distribution of vaccines served to further reinforce this. New areas of productive activity have (potentially) opened up and, with that, the need for new knowledges and skills. 
The second is that it brought to the forefront a broader notion of work by highlighting the importance of the social economy and the fragility of the informal sector. The pandemic shifted the definition of who carries out valuable work from those who earn the greatest individual wealth to essential workers who deliver essential social services. While business relief was provided to support companies during Lockdown Levels Five and Four, no support was provided to the informal sector or to small and micro enterprises (SMEs). This is despite survivalist entrepreneurship and micro businesses being responsible for the majority of new jobs in South Africa. As far back as the early 2000s, Altman (2003) and Bhorat and Ooshuizen (2009) agreed that the net gains in employment arose mainly in the informal sector and particularly for low-skilled and semi-skilled jobs. This trend has continued to the present with 3 million people (approximately $20 \%$ of total employment) working in the informal sector (StatsSA, 2019). Notwithstanding the ongoing debate on whether the totals for employment in the informal sector provided by StatsSA are undercounted or an actual reflection, there can be little argument that the informal sector accounts for a large share of total employment in South Africa.

The third is that it severely increased retrenchments and, with it, unemployment. The National Income Dynamics Coronavirus Rapid Mobile Survey (CRAM) found that approximately 3 million people who were employed in February 2020 were either temporarily or permanently unemployed by June 2020 (Kean \& Armstrong, 2020). The workers with the lowest income and with the most fragile links to the labour market were the worst affected (Kean \& Armstrong, 2020). What accentuates this concern is that the impact on training has been severe. The Technical Vocational Education and Training (TVET) colleges lost two rounds of student intake in 2020. Work Integrated Learning (WIL), historically constrained by limited employer buy-in, was brought to a halt in 2020. Recovery has been constrained by COVID-19 restrictions on the number of workers allowed on the shopfloor and employer hesitancies to allow trainees into the workplace.

Stark job losses in the formal sector because of COVID-19 (Kean \& Armstrong, 2020), a steady increase in survivalist entrepreneurship, and a critical need for skills oriented towards the needs of the social economy is now common cause everywhere, other than in the framing of NSPS that wilfully continues to draw its information set from large enterprises in the formal sector and doggedly stumbles forward in an orthodoxy that has proven itself unfit for addressing the socio-economic challenges facing South Africa and the rapid changes taking place in the world of work.

I go on to discuss the contribution that the capability approach brings to our thinking about skills planning. I begin with a broad introduction to the central tenets of the capabilities approach. Thereafter I discuss the contribution that the capability approach brings by focusing on five dimensions inherent in the capability approach. These five dimensions are: (i) "conversion rates" (Drèze and Sen, 1992, p. 3), (ii) "informational basis of judgement" (Sen, 1990, p. 111), (iii) "the capability for voice" (Bonvin \& Michael, 2009, p. 572), (iv) "the capability for education" (Bonvin, 2019, p. 279) and (v) relational capabilities (Longshore Smith \& Seward, 2005). This is followed by the penultimate section in which I 
discuss the contribution that the capability approach brings to our framing of a broader approach to skills planning. It shifts the focus from expanding human capital to a focus on expanding human capabilities by providing seven dimensions that form a framework for an emancipatory approach to skills planning. The final section is the conclusion in which I synthesise the key arguments of this article.

\section{The capabilities (human development) approach}

The capabilities approach, while not developed as an approach for skills development, brings a promising perspective to our thinking about NSPS. Known best as an approach for measuring human wellbeing, the approach distinguishes between capabilities (a person's or group's meaningful opportunities and the freedom to choose therefrom) and functionings (achievements). The distinction between capabilities and functionings concentrates attention on what people are able to choose to be and to do with the resources that they have and in the contexts in which they live (Sen, 2009).

So, what does the capabilities approach bring to our thinking about NSPS? I explore the contribution that it brings by focusing on the five tenets of the capability approach listed above.

\section{Conversion rates}

The capability approach distinguishes between capabilities and functionings but also between resources and capabilities. The distinction between resources and capabilities, and between capabilities and functionings, brings to the forefront the social justice imperative of focusing on capabilities and the extent to which institutional and socio-economic arrangements serve to either expand or constrict capabilities. The distinction recognises that people differ in their ability to convert resources into valued functionings (Sen, 1992). A focus on conversion factors allows a distinction to be made between the marginal productivity of an individual and the social and cultural factors such as race, class, gender, and location that affect the ability to convert skills and qualifications into meaningful livelihoods. Shining a light on the distinction between resources and capabilities demands a focus on the areas requiring conversion rate correction (Chiappero-Martinetti \& Sabadash, 2014).

By focusing directly on interventions that improve the wellbeing of people's lives and their ability to live and work in ways that they have reason to value, rather than on productivity, profits, or economic growth, the capability approach focuses attention on inequalities in accessing knowledge and skills but also on differences in people's ability to capitalise on their skills in the labour market and in their lives. The argument that is made is that NSPS contributes to unemployment and poverty by identifying the right education that allows the unemployed to be trained in targeted areas that increase the labour market competitiveness of their qualification. This argument has proven ineffective for a host of reasons, one of which is that it ignores the conversion rate corrections required for people to utilise their knowledge and skills and to convert them into a meaningful livelihood. 


\section{Informational basis of judgement for justice (IBJJ)}

Bonvin and Farvaque (2005) distinguished between the substantive level and the procedural level of information sets. The substantive level involves the actual information on which NSPS is built and distinguishes between the categories of information that are regarded as important and included, and those that are excluded as unimportant. The procedural level focuses on the processes of inclusion or exclusion that take place during the compilation of the information set that underpins NSPS.

At both the substantive and procedural levels the information set for South Africa's NSPS privileges employers. The information set is aggregated upwards from work place skills plans of enterprises (mostly large enterprises of 150+ employees). These are aggregated into Sector Skills Plans that are then further aggregated to form national skills plans that identify Occupations in High Demand (OIHD). The list of OIHD is used to support the planning of the Department of Higher Education and Training with respect to enrolment totals and resource allocations. The list also informs the allocation of work visas by the Department of Home Affairs and is expected to inform the strategic plans of Post School Education and Training (PSET) institutions (Reddy et al., 2018).

At both the substantive and procedural levels, NSPS is neglectful of the knowledges and skills needed for the informal economy, the social economy, the green economy, and other essential work such as care work and community work. Ironically, NSPS has also proven ineffective at meeting the needs of formal sector enterprises since it ignores sectoral and company-based needs (Allais et al., 2021).

\section{The capability for voice}

The capability for voice or "the ability to voice one's concerns and make them count" (Bonvin and Michael, 2009, p. 569) expands participation at the procedural level. Sen (1999) warned that the failure to take seriously democratic participation and the need to expand the capability for voice (Dif-Pradalier, et al., 2012) risks "targeting achievements [being] quite different from targeting-attempts" (Sen, 1999, p. 137). In this view, democratic participation puts the accuracy of the information set and the reasons for which it is being developed to public scrutiny. The difference is on what Crocker (2008, p. 320) terms "deeper democracies" in which citizens are engaged in decision making as opposed to "shallow democracies" in which democratic participation is limited to voting.

Dean et al. (2005, p. 11) suggested that the capability for voice functions best in an environment in which the state is transformed into what they call a "capability state." The capability state differs from the neoliberal state in that decisions are made through public deliberation at the local level rather than centrally through statistical information and managerially defined targets. "Co-ordinating conventions" (Dean et al., 2005, p. 11) are established to provide opportunities for citizens to deliberate on policies and practices and the extent to which they believe that these would expand meaningful opportunities and human flourishing (Dean et al., 2005). The capability state would "mediate rather than prescribe 
[and] jobseekers [would have the opportunity to] ... argue for . . . their life plans." In this model, the focus shifts from the development of datasets to the establishment of "mechanisms for negotiation" and the "procurement of rights in negotiation" (Dean et al., 2005, p. 11).

Despite almost a quarter century of National Skills Development Strategies and huge financial investments into improving the reliability of skills information, NSPS as currently constructed is fraught with challenges including "putative skills mismatches" such as increasing the number of artisans despite artisans remaining unemployed (Allais et al., 2021, p. 650). Expanding the capability for voice would improve the relevance of training and the likelihood that implementation processes will achieve the set-out goals. It would shift from providing training opportunities to youth as if they are "motionless patients" (Sen, 1999, p. 137) to an approach that builds deep democracies in which youth are active participants in shaping the knowledge and skills required for their futures. The capability for voice represents an ontological shift away from the homo economicus that underpins NSPS to an approach that recognises the diversity and agency of youth.

\section{Broader conceptualisations of work}

Powell \& McGrath (2019b) drew on the three aspects of work outlined by Sen (1975): the production aspect; the recognition aspect; and the income aspect. The production aspect speaks to the contribution of labour to the production of things that are needed. The recognition aspect to the self-identity and self-worth that comes from being engaged in something worthwhile, and the income aspect to the livelihoods earned through productive labour. NSPS separates the spheres of working (production) and living (consumption). In this view, enterprises produce goods and services, and individuals provide their productive labour (Leßmann, 2012). Sen's notion of three dimensions challenges this separation between production and consumption by including labour that is unpaid and undertaken in the household (the production aspect) and labour that increases dignity, recognition, and respect (the recognition aspect) (Leßmann, 2012). Sen's (1975) argument is that work is intrinsically valuable for human flourishing across these multiple dimensions and is not reducible to earning an income. In contrast to this broader account of work presented by the capability approach, work in NSPS is understood monolithically as wage labour undertaken in the formal sector and mainly in large enterprises in this sector.

Bonvin (2012) emphasised that the focus has to be on the "“capability for work' or the real freedom to choose the job one has reason to value" (p. 10). Here the quality of the work matters as does the dignity and respect of the worker. In Powell and McGrath, 2019b, McGrath and I reported on the work experiences of a small cohort of young people who live in an urban township in Gqeberha. The analysis showed that all the young people who had some work experience had gained that experience by working in conditions that were damaging to their wellbeing. We also found that almost all the young people who participated in the study earned below the legal minimum wage with some earning nothing at all. The worst case was that of a young woman who worked for almost two years as an intern without any earnings or stipend support. These findings align with those of Bhorat et al. (2012, p. 284) who found a "disturbingly high" rate of minimum wage violation in South Africa with 
$44 \%$ of workers paid wages below the legislated minimum [and an] average shortfall of $35 \%$ of the minimum wage.

While NSPS focuses on the skills needed for formal employment, in my work with young people in Gqeberha, I found that they were concerned with the recognition aspect almost as much as they were with the income aspect since they aspired to contribute to the development of their community and to being recognised and respected for that contribution (Powell, 2020). Dejaeghere's (2020) work, undertaken with youth in East Africa, similarly found youth emphasising the importance of dignity and recognition in their community.

In contrast to the capability for work, NSPS focuses on only the production aspect of work as it affects large formal sector enterprises, ignores the recognition aspect of work, and turns a blind eye to gross human rights and wage violations that severely affect the income aspect of work.

\section{The capability for education}

NSPS views skills instrumentally (Allais, 2012) as a means of meeting the goals of productivity and economic growth. In opposition to human capital theory that focuses on the economic merits of education, Robeyns (2006) modified the typology developed by Drèze and Sen (2002) to identify three roles for education and training: (i) the instrumental role; (ii) the intrinsic role; and (iii) the empowerment role. Cutting across all three of these roles is a commitment to expanding social justice since education has a central role in expanding capabilities that make other meaningful opportunities possible (Unterhalter, 2013).

The instrumental role prepares a person to better function in their family and society by providing the skills and qualifications required to participate in work and in society. This could be what Sen (1975) described as productive work, or it could be socially useful work, or it could be wage labour within the formal or informal economy. The instrumental role goes beyond the knowledge and skills needed for productivity and for protection from unemployment to include that needed for living in the world in relationship to oneself, to others, and to the environment.

The instrumental role includes developing the communication skills needed for dialogues and public deliberation. Expanding the ability to engage in public dialogues provides individuals and groups with the skills needed to act collectively towards transforming oppressive social and economic structures. The capability for voice should be contained in education in ways that encourage learners to participate in public deliberations and in policy decision making and thus practice the capability for voice.

Central to the instrumental role is the tension that exists between human capital and human capabilities. Sen (1999) contended that human capital and human capability are intimately connected but that human capital relates to only those aspects utilised in production and is therefore a narrower concept than human capabilities, which term relates to all aspects necessary for human flourishing. Brown et al. (2020) critiqued Sen's (1999) understanding of 
human capital as existing as a subset of human capability since they believe that this risks "bracket[ing] off economic aspects of life as human capital as opposed to human capabilities" (p. 146). In their contention, "[S]upply needs to be redefined as building individual and social capabilities that give people permission to think and act in order to take control of their lives" (p. 153) rather than in the bankruptcy model of labour supply that underpins supply and demand skills planning approaches.

The empowerment and distributive roles of education come closer to Brown et al.'s (2020) conception of supply that locates in what Sen $(1993,519)$ described as the "process aspect of freedom" that is concerned with the freedom that an individual has to choose from a range of opportunities. Leßmann (2009) argued that social policy tends to focus on the "opportunity aspect" (Sen, 1993, p. 519) of freedom by expanding opportunities available to a person but that it is hugely neglectful of the process aspect of freedom that is critical for expanding the capability to choose in the poor.

As a learnt capability, or what Nussbaum (2011, p.21) calls an "internal capability", a critical role for education in poverty alleviation and in redressing unemployment is to expand the capability to choose (Leßmann, 2009) and the capability to aspire (Hart, 2012; Powell, 2012). The "capability to aspire" (Powell, 2012, p. 11) helps individuals and groups to correct for adaptive preferences. These exist when people living in dire circumstances adapt their preferences to allow themselves to become content with their challenging situation in order to better cope with their lives (Sen, 1984). Here education has an important role to play through empowering individuals and communities to expand their aspirations in a manner that allows them to aspire towards and collectively create meaningful capabilities that are not currently available to them (Watts et al., 2008). As Fataar (2010) has reminded us, "[A]s a navigational capacity, the more the capacity to aspire is exercised, the more its potential for changing the terms of recognition under which the poor must operate" (p. 35).

In the capabilities approach, education has a transformative role to play through identifying, evaluating, and redressing social injustices. In this view learners are actively engaged in learning how to learn, and in learning about themselves as creative beings in and of the world (Bonvin, 2019). Education and training understood in this sense is transformative rather than reproductive and contributes to the creation of active citizens able to act for a more capability enhancing economy.

Narrow instrumental and mechanistic understandings of skills that underpin NSPS risks education responses that are framed within deficit banking models and that produce human ill-being. Instead, the capability approach emphasises, through the intrinsic role of education, the human right to learn for the sheer joy, personal development, and self-fulfilment that learning provides. The intrinsic role recognises that the freedom and the ability to choose from a range of learning opportunities directed towards the different role(s) of education is of intrinsic importance to a person's wellbeing since "acting freely" and "being able to choose are ... directly conducive to wellbeing” (Sen, 1992, p. 50). 


\section{Relational capabilities and social ecosystem thinking}

Early accounts of the capability approach were critiqued for neglecting power and the social and structural contexts that serve to maintain inequalities in capabilities and functionings (see, for example, Gore, 1997; Ibrahim, 2011; Stewart, 2005). More recent understandings have accepted that "while the individual is seen as the person to whom relational deprivation occurs ... the focus of the capability analysis . . cannot but be unescapably social" (Sen, 2000 , p. 8). Capabilities, then, are not possessed by an individual but are socially relational and exist as an interaction between the individual and the social and economic structures of a society (Longshore Smith \& Seward, 2005).

Dejaeghere (2020) took this further by arguing that "the question of power in the capabilities approach mitigates against individualized and decontextualized notions of agency and wellbeing" (p. 20). She suggested a set of questions that can be used in the capability approach to illuminate the role that education and training might play in reproducing or addressing inequalities. Her questions draw from intersectional approaches in that they include consideration of race, gender, and decoloniality and acknowledge the historical conditions that result in oppression and inequality. In both cases relationships to power and marginality are brought into focus. The three questions framed by Dejaeghere (2020, p. 24) are provided in partially edited form below.

- What are the historical conditions, or pre-colonial, colonial, and postcolonial relations that have excluded some young people? How do these economic, political, social, and discursive forms of power continue to exclude?

- Who is being "Othered" by whom, in relation to education? What are the changing politics of belonging in relation to education?

- How are patriarchal, race, or class regimes perpetuated through education?

These three questions provide a useful framework for thinking about skills planning since they form the basis for responding to low skills formations and for responding to social injustice by expanding access to meaningful opportunities. If skills development is to achieve its stated goal of disrupting inequalities and addressing poverty and unemployment, it has to be located in a relational account that demands a focus on unequal "power and oppression [as] constituent components of [the] capability set" Longshore Smith \& Seward (2009, p. 230). Such a relational account would recognise the economic as well as the socially transformative role of skills, while, at the same time, acknowledging the power relations that maintain and reproduce existing inequalities.

The relationality of capabilities is evident in understandings held of conversion factors which can be personal (such as gender, physical barriers/enablements, or aspirations), social (such as socio-economic, institutional, cultural, or the demands of the labour market), or environmental (such as water shortages) (Robeyns, 2006). Conversion factors can also be intersectional. Bringing an intersectional analysis into a relational account of capabilities allows "race, gender, and class ... and relations of power manifested in social, economic, and political injustices in societies" to be made visible (Dejaeghere, 2020, p. 23). In this 
understanding, the conversion of capabilities into meaningful functionings will occur only in institutional and structural circumstances that allow for and enable that conversion. This, in turn, demands the inclusion of a political economy approach for better understanding the institutions and structures that enable or constrain capabilities and that advance or inhibit conversion rate correction.

One approach to skills development that aligns well with the principles of the capability approach is the social ecosystem model (SEM). SEM locates itself in a political economy approach and enables conversion rate correction by proposing a model for the collective coconstruction of social ecosystems that "nurture inclusive, sustainable educational, economic and social development" (Spours, 2019a, p. 11). Essentially, it is a commitment to understanding and developing skills as they are lived in context and as they are lived in relationship to others and to the planet (Grainger \& Spours, 2018).

SEM expands capabilities in "place based" (Spours, 2019a, p. 3) social formations that work towards inclusive economic growth and sustainable living by connecting the three dimensions of working, living, and learning. In Spours's (2019a) explanation of these, the working dimension talks to social formations who work towards better and more sustainable jobs. This could include the development of new social ecosystems that focus on critical local, and community needs such as healthcare, food sovereignty, and the development and maintenance of public infrastructure. The living dimension talks to the dimensions needed by communities such as affordable housing, accessible healthcare, the development of adequate childcare facilities, care of the elderly, and the development of township economies. The aim is to build sustainable approaches to living that reinforce local identity and create attractive living environments that are close to work (Spours, 2019b). The learning dimension cuts across the working and living dimensions in that it supports the participation of people in the economy while at the same allows access to lifelong learning that enhances flourishing lives along well-defined learning and citizen pathways. Alike to the capability approach, work in SEM is understood in its broadest sense to include care work, community work, and wage labour.

Central to SEM is the use of the biological metaphor of ecosystems to reflect the combined emphasis on inter- and intra-dependent relationships through "regional place-based social formations" (Spours, 2019a, p. 3). These social formations include education and training, communities, government, and employers who form "horizontal network[s]" (Spours, 2019b, p. 24 to connect and bring about transformations in working, living, and learning so that regional economies and living environments can be sustainably transformed. Spours (2019b, p. 15) termed these horizontal networks "collaborative horizontalities" but in 2021 he expanded the term to refer to "the radical horizontal" (2021, para. 11). The idea of the radical horizontal highlights the importance of progressive activism to respond to the oppressions of neoliberalism and to shape "vibrant sites of political participation" (2021, para. 12) that celebrate human capacities to re-engineer, through co-operative, mutually constructed, and participatory approaches, their social relationships and their relationship with the planet. 
Universities and TVET colleges are central as engaged civic actors (Hodgson \& Spours, 2016) that serve as "anchor institutions" (Spours, 2019b, p. 15) supporting the participatory engagements of the social ecosystem. In SEM, qualifications reform and the development of learning pathways and citizen pathways is co-constructed through co-operative democratic participation in networks that work together to develop new meaningful jobs oriented towards sustainable living (Lotz-Sisitka, 2019).

"Facilitating verticalities" (Spours, 2019b, p. 15) are hierarchical structures governed by institutions, systems, and policies that are regulated by state. These verticalities can exist as enablers or disenablers of the social ecosystem with Spours (2021) having suggested that "the effects of national or governmental state on local civil society . . have been broadly negative (2021, para. 14). The South African TVET colleges, for example, are managed as national competencies. Outside of small pockets of innovation in occupational programmes, the TVET colleges are locked into providing nationally designed programmes and are funded according to their enrolments in these programmes. "Mediation", or "45 degree mediation" (Spours, 2019b, p. 17), recognises that the vertical and horizontal components connect in a dynamic interaction (Spours, 2021) which might include the leadership of ecosystems and technological connectivity (Spour, 2019b). Lotz-Sisitka (2019) addressed the possibilities that exist in this mediation space for "experimental platforms" such as joined-up skills programmes and socialised digital platforms (2019, p. 119).

Locating knowledge and skills in the contexts in which they are needed and orienting skills towards meaningful livelihoods and sustainable living and working environments is radically different to the supply and demand orthodoxy that underpins NSPS. In the current approach, skills planning is aggregated nationally and disbursed as lists of OIHD from the centre to the periphery with PSET institutions at the receiving end of these lists. In contrast to NSPS, SEM opposes the idea of centralised and hierarchical leadership, aiming, instead, for collective ownership of the social ecosystem and for co-construction of skill needs. In this sense, SEM aims to expand the capability for voice by putting power back into the hands of marginalised PSET institutions such as our TVET and community colleges and by insisting that communities are in the driving seat.

SEM could be understood as an agential space that aligns with the aims of the capability approach by expanding opportunities for capability expansion through expanding the capability for voice, the capability for education, and the capability for work. Simultaneously through its focus on relations and relationality it potentially addresses conversion factors that constrain individuals and groups from accessing knowledge and skills and then converting these into meaningful livelihoods and sustainable living. SEM does this by changing the information base at the substantive and procedural levels. At the substantive level the information that is valued is that which is co-constructed and that contributes to sustainable and inclusive regional development. At the procedural level the shift is away from the deductivist approach applied in NSPS and towards an inductivist logic that takes seriously the capability for voice through the establishment of participatory approaches. The participatory approach adopted by SEM expands the capability to aspire by enabling individuals and 
groups to collectively imagine and create future opportunities that do not currently exist for them.

\section{Towards a broader approach for skills planning}

Table 1 synthesizes the contribution that the capability approach, informed by a relational approach and supplemented by SEM, brings to a broader approach to skills planning. It organises this synthesis into seven dimensions required for an emancipatory approach to skills planning.

The first and most important of these dimensions focuses on the goal and purposes of skills planning. In opposition to NSPS, in which skills are targeted towards expanding productivity, profits, and economic growth, the capability approach focuses on expanding human capabilities and a capability enhancing society. Economic growth in the capability approach represents the means rather than the end of developmental goals (Sen, 1999). The focus in the capability approach is on expanding the freedoms that human beings have to be and to do and the agency to choose between these beings and doings. Embedded in this paradigmatic shift, knowledge and skills are oriented towards the public good and towards addressing complex social challenges that inhibit human development.

The second and third of these dimensions focus on the economy and education and, cutting across these two dimensions, is the relationship between the economy and education. In terms of Dimension 3, The Economy, the capability approach insists on a broader view of the economy that includes the formal sector but that also includes the informal and social economy. Here workers, and the knowledge and skills with which they are endowed, are not understood as being supplied to the economy but as being active participants with the potential of shaping, through public deliberation and social movements, the work that is available and their access to it. SEM deepens the capability approach by emphasizing the importance of inter- and intra-dependent relationships at the local level that collectively coconstruct the skills needed for working, living, and learning.

The capability approach includes a focus on removing the substantive unfreedoms that hinder people from living a fulfilled life and acknowledges that access to the labour market does not serve to protect people from exploitative labour market practices (Bonvin, 2019). Here the SEM model provides valuable insights into the ways in which participatory co-construction of skill needs and the development of learning pathways and citizen pathways could serve as conversion rate correction and as protection from exploitative labour market practices.

The role of education and training (captured in Dimension 4: Education and Training) in skills planning is not simply to be responsive to the needs of the labour market as recipients of the list of OIHD. In the capability approach, education and training are central players with the roles of education including the instrumental, the intrinsic, and the empowerment aspects. In the empowerment aspects, the role that education plays in expanding the capability for voice and the capability to aspire are critical for enabling civic engagement. In this view, knowledge and skills are not simply reproductive or responsive, but potentially 
transformative at the level of the individual and the society. SEM takes this further by framing education institutions as key "anchor institutions" (Spours, 2019b, p. 15) in the establishment of social ecosystems and by providing a model for experimentation towards the development of inclusive and sustainable regional development.

Dimension 5 addresses the methodological approach adopted by NSPS and the approach that a capability approach brings to our thinking about skills planning. The information set that the capability approach compiles is different to that compiled by NSPS at both the substantive and the procedural levels. At the substantive dimension, NSPS focuses on the skill needs of the formal sector (mainly large employers in the formal sector). The capability approach, however, adopts a broad notion of work that includes work in the social economy, the green economy, the informal economy, as well as the formal economy. At the procedural level the capability approach insists that the recipients of development be democratically included in deciding on the knowledge and skills programmes that are to be provided and the reasons for which they are provided. This is radically different from current approaches in which skills programmes are offered and youth are invited to apply to participate.

Contrary to NSPS which is based on a deductivist logic that aggregates from WSP to national OIHD lists, the capability approach, particularly when framed within relational capabilities, applies an inductivist approach. Knowledge is co-constructed in regionally developed partnerships that include communities, education, employers, and government. The capability approach insists that skills planning takes place at a local or regional level and that differences in identities and regions are not only recognised but celebrated. Expanding the procedural level would mean shifting the focus of skills planning from the skills needed for profit to the skills needed for social and economic transformation. It would mean shifting from current NSPS approaches that rely on historic data to identify OIHD to one that allows skills needs to be co-constructed through public reason. This, in turn, opens the possibility for rapid and contextually defined responses to education and training needs.

Dimension 6: The Anthropological Dimension (adapted from Bonvin, 2019) shows that the capability approach brings a shift to our understanding of the human. In direct opposition to NSPS that disregards as irrelevant the aspiration of citizens to contribute to their local communities, the agency and aspirations of youth are given centre stage. While NSPS ignores the skills that already exist in communities, opting instead for a deficit model oriented towards the needs of large employers, the capability approach celebrates people as having value in and of themselves. NSPS sees as irrelevant what matters to youth and the communities in which they live and ignores the agency that people have to transform their environments and their communities. The capability approach, in direct opposition to this, recognises that understanding the capabilities that people have reason to value is critical for skills planning. SEM provides a concrete model by which the capabilities that matter can be discerned, co-constructed, and responded to.

Dimension 7 is concerned with the development or transformation logic that the capability approach brings to our thinking of skills planning as compared to NSPS that locates in a productivist logic that assumes that improving knowledge and skills will improve economic 
productivity that will then, in turn, address unemployment and alleviate poverty (Anderson, 2009). This logic, grounded in neoliberalism, has held firm despite the strongest evidence being that economic growth not only does not trickle down to the poor (Bourguignon, 2003; Fosu, 2010) but instead of raising all boats has, because of the monopolisation of capital in the hands of a few, served to increase inequality (Piketty, 2018). In this logic, skills planning focuses on identifying the right education and expanding access to it in the hope that this will address inequalities, poverty, and unemployment. In direct opposition to the dominant skills orthodoxy, the capability approach focuses on expanding access to meaningful opportunities, addressing conversion rate corrections, and removing substantive unfreedoms (Powell \& McGrath, 2019a).

\section{Table 1}

Comparing the underpinning logic of the NSPS to the capability approach (Source: Own elaboration that modifies Bonvin, 2019)

\begin{tabular}{|c|c|c|}
\hline APPROACHES & CURRENT NSPS & CAPABILITY APPROACH \\
\hline \multicolumn{3}{|l|}{ Dimension 1: Goal } \\
\hline Goal & $\begin{array}{l}\text { Expand economic growth and firm } \\
\text { productivity and at the same time } \\
\text { address unemployment. }\end{array}$ & $\begin{array}{l}\text { Advance a capability enhancing } \\
\text { society by expanding the capability } \\
\text { for education and the capabilities for } \\
\text { work. }\end{array}$ \\
\hline \multicolumn{3}{|c|}{ Dimension 2: The Economy } \\
\hline Economy & $\begin{array}{l}\text { Formal economy (mainly large } \\
\text { enterprises) }\end{array}$ & $\begin{array}{l}\text { Formal, informal labour, and social } \\
\text { economy }\end{array}$ \\
\hline Link to labour market & Reproductive (produces workers) & $\begin{array}{l}\text { Transformative: creates agential } \\
\text { citizens able to choose and work. }\end{array}$ \\
\hline Understanding of work & $\begin{array}{l}\text { Employment in the formal sector } \\
\text { (mainly in large enterprises of } 150+ \\
\text { employees) }\end{array}$ & $\begin{array}{l}\text { Understands work in its broadest } \\
\text { sense to include socially valuable } \\
\text { work such as care work and } \\
\text { community work. }\end{array}$ \\
\hline \multicolumn{3}{|c|}{ Dimension 3: Education and Training } \\
\hline Understanding of skills & $\begin{array}{l}\text { Neutral, mechanistic, and } \\
\text { instrumental }\end{array}$ & $\begin{array}{l}\text { Embedded in socio-cultural and } \\
\text { economic contexts. }\end{array}$ \\
\hline Education and Training & Instrumental function & $\begin{array}{l}\text { Instrumental, intrinsic, and } \\
\text { empowerment function }\end{array}$ \\
\hline $\begin{array}{r}\text { Relationship of education } \\
\text { to skills planning }\end{array}$ & $\begin{array}{l}\text { Education and training institutions are } \\
\text { to be responsive to identified scarce } \\
\text { and critical skills and the OIHD. }\end{array}$ & $\begin{array}{l}\text { Education and training are central } \\
\text { players in expanding the capability } \\
\text { for voice, the capability to aspire } \\
\text { and for redressing adaptive } \\
\text { preferences. }\end{array}$ \\
\hline Redress approaches & Expand access education and training. & $\begin{array}{l}\text { Expand access to capabilities } \\
\text { (meaningful opportunities) and } \\
\text { address conversion rate corrections. }\end{array}$ \\
\hline
\end{tabular}




\begin{tabular}{|c|c|c|}
\hline \multicolumn{3}{|c|}{ Dimension 4: Methodology } \\
\hline Information set & $\begin{array}{l}\text { Predictive based on past knowledge } \\
\text { and skills needs. }\end{array}$ & Co-constructed and flexible \\
\hline Methodology & Deductivist and causal & Co-constructed and inductivist logic \\
\hline \multicolumn{3}{|c|}{ Dimension 5: Anthropological (adapted from Bonvin, 2019) } \\
\hline $\begin{array}{l}\text { Understanding of the } \\
\text { individual }\end{array}$ & Rational individualist & Ethical individualism \\
\hline $\begin{array}{l}\text { Relationship between } \\
\text { human beings and the } \\
\text { economy }\end{array}$ & $\begin{array}{l}\text { Human beings as a means to } \\
\text { economic growth }\end{array}$ & $\begin{array}{l}\text { Human beings as the ends of } \\
\text { economic growth }\end{array}$ \\
\hline \multicolumn{3}{|c|}{ Dimension 6: Transformation } \\
\hline Redress approaches & $\begin{array}{l}\text { Expand access to education and } \\
\text { training. }\end{array}$ & $\begin{array}{l}\text { Expand access to capabilities } \\
\text { (meaningful opportunities) and } \\
\text { address conversion rate corrections. }\end{array}$ \\
\hline
\end{tabular}

\section{Conclusion}

In outcome, if not by design, the introduction of South Africa's skills planning approach in the mid-1990s has contributed to maintaining, if not deepening, the entrenched social and economic divisions that existed in apartheid. A skills planning mechanism that ignores the reality of the labour market and that hopes, based on wishful thinking and a basket of neoliberal policies, that responding to the skills needs of large employers will somehow address unemployment will, as it has done, face increasing numbers of learners excluded from the benefits of such planning. Ultimately, a skills planning mechanism that does not squarely address the onerous task of including the skills needs of the millions who work in the informal sector, in small and micro enterprises, in care work, and those who are permanently excluded from wage labour, is destined to further reproduce inequality along the current lines of marginalisation, i.e., with young black people, particularly young rural women, being the most affected.

This article makes four cross cutting contributions. First, and at its most simplistic, it insists that we bring NSPS into the spotlight and that we consider again the role, function, and purpose of skills planning as a central and extremely costly aspect of South Africa's skills development approach. Second, it argues in support of Balwanz and Ngcwangu (2016) that "South Africa needs a broader skills development vision" (p. 31). Third, it argues that any renewed framework for skills planning must be underpinned by the goal of expanding human flourishing, rather than economic growth, production, or profits.

Fourth, and finally, it draws on the capabilities approach to suggest seven dimensions as the underpinning logics of an emancipatory approach to skills planning. While all seven of the dimensions matter, central to these is the need to take seriously the following aspects. First 
would be the need for a broader understanding of what constitutes work that includes work that takes place in the informal sector and the social economy. Second is the need to build democratic systems (such as social skills ecosystems) in which skills needs can be coconstructed in a participatory manner. Third is the need to move away from instrumental understandings of skills and to recognise the multiple roles that education and training could potentially play in expanding human flourishing through expanding the capability for work, the capability for voice, and the capability for education. Fourth is the need to address the conversion factors that constrain individuals and groups from converting knowledge and skills into flourishing lives. This includes acknowledging the power and oppressions that have served to reproduce the current system. Here SEM is suggested as an innovative approach for establishing at regional levels social ecosystems that bring employers, communities, education institutions, and government together to identify the knowledges and skills needed for sustainable inclusive regional economies.

The core argument is that there is now an urgent need for new approaches to skills planning that are informed by a different set of assumptions, driven by a different set of indicators, inclusive of different voices, undertaken through different processes and, importantly, driven by a different set of goals. Responding to the call for a broader approach to skills planning and taking seriously the seven dimensions of an emancipatory skills planning system will require an alternative vision not only of skills and of work, but of the economy as a whole. As Stiglitz (2020), mentioned earlier in this paper, argued, any chance of building back better would require nothing less than a "comprehensive rewriting of the rules of the economy" (Stiglitz, 2020, para. 6) and with it, of skills development and skills planning.

\section{References}

Allais, S. (2012). Will skills save us? Rethinking the relationships between vocational education, skills development policies, and social policy in South Africa. International Journal of Educational Development, 32(5), 632-642. https://doi.org/10.1016/j.ijedudev.2012.01.001

Allais, S., Schoer, V., Marock, C., \& Kgalema, V. (2021). Rethinking 'supply and demand' of Technical and Vocational Education and Training: Insights from a company survey in three manufacturing sectors in South Africa. Journal of Education and Work,34(5/6), 649-662.

Altman, M. (2003). The state of employment and unemployment in South Africa. In J. Daniel, A. habib \& R. Southall (Eds.), State of the Nation: South Africa 2003-2004 (pp. 158-183). Human Sciences Research Council Press.

Anderson, D. (2009). Productivism and ecologism: Changing dis/courses in TVET. In J. Fien, R. Maclean \& M-G. Park (Eds.), Work, learning and sustainable development (pp. 35-57). Springer. 
Balwanz, D., \& Ngcwangu, S. (2016). Seven problems with the "scarce skills" discourse in South Africa. South African Journal of Higher Education, 30(2), 31-53.

Bhorat, H., \& Oosthuizen, M. (2009). Employment shifts and the "jobless growth" debate. In A. Kraak \& K. Press (Eds.), Human Resources Development Review. 2008 (pp. 5069). Human Sciences Research Council Press.

Bhorat, H., Kanbur, R., \& Mayet, N. (2012). Minimum wage violation in South Africa. International Labour Review, 151(3), 277-287.

Bonvin, J-M. (2012). Individual working lives and collective action. An introduction to capability for work and capability for voice. Transfer, 18(1), 9-18.

Bonvin, J-M. (2019). Vocational Education and Training beyond human capital: A capability approach. In Simon McGrath, M. Mulder, J. Papier \& R. Suart (Eds.), Handbook of Vocational Education and Training: Developments in the changing world of work, (pp. 273-289). Springer.

Bonvin, J-M., \& Farvaque, N. (2005). Promoting capability for work. The role of local actors. In Capability and justice. Towards structural transformation. Kluwer Academic Press.

Bonvin, J-M., \& Michael, O. (2009). Activation policies and organisational innovation: The added value of the Capability Approach. International Journal of Sociology and Social Policy, 29(11/12), 565-574.

Bourguignon, F. (2003). The growth elasticity of poverty reduction: Explaining heterogeneity across countries and time periods. In T. Eicher \& S. Turnovski (Eds.), Growth and inequality (pp. 3-26). MIT Press.

Brown, P. (2020). Some observations on the race to higher education, digital technologies and the future of work. Journal of Education and Work, 33(7/8), 491-499.

Brown, P., Lauder, H., \& Cheung, Y. S. (2020). The Death of human capital? Its failed promise and how to renew it in an age of disruption. Oxford University Press.

Chiappero-Martinetti, E., \& Sabadash, A. (2014). Integrating human capital and human capabilities in understanding the value of education. In S. Ibrahim \& T. Meera (Eds.), The capability approach, from theory to practice (pp. 206-230). Palgrave Macmillan.

Cooper, A., Swartz, S., \& Mahali, A. (2019). Disentangled, decentred and democratised: Youth studies for the Global South. Journal of Youth Studies, 22(1), 29-45.

Crocker, D. A. (2008). Ethics of Global Development. Cambridge University Press.

Dean, H., Bonvin, J-M., Vielle, P., \& Farvaque, N. (2005). Developing capabilities and rights in welfare-to-work policies. European Societies, 7(1), 3-26. 
Dejaeghere, J. G. (2020). Reconceptualizing educational capabilities: A relational capability theory for redressing inequalities. Journal of Human Development and Capabilities, 21(1), 17-35.

Dif-Pradalier, M., Rosenstein, E., \& Bonvin, J-M. (2012). Vocational training as an integration opportunity for struggling young adults? A Swiss case study. Social Work and Society, 10(1), 1-16.

Drèze, J., \& Sen, A. (2002). India: Development and participation. Oxford University Press.

Fataar, A. (2010). Youth self-formation and the 'capacity to aspire': The itinerant 'schooled' career of Fuzile Ali across post-apartheid space. Perspectives in Education, 28(3), 3445 .

Fosu, A. K. (2010). Does inequality constrain poverty reduction programs? Evidence from Africa. Journal of Policy Modeling, 32(5), 818-827.

Gore, C. (1997). Irreducibly social goods and the informational basis of Amartya Sen's capability approach. Journal of International Development, 9(2), 235-250.

Grainger, P., \& Spours, K. (2018). A social ecosystem model: A new paradigm for skills development? https://www.g20-insights.org/wp-content/uploads/2018/07/a-socialecosystem-model-a-new-paradigm-for-skills-development-1532510354.pdf

Hart, C. (2012). Aspirations, education and social justice: Applying Sen and Bourdieu. Bloomsbury.

Hodgson, A., \& Spours, K. (2016). The evolution of social ecosystem thinking: Its relevance for education, economic development and localities: A stimulus paper. Institute of Education. https://discovery.ucl.ac.uk/id/eprint/1537510/3/Spours_Ecosystem thinking Stimulus Paper.pdf

Ibrahim, S. (2011). From individual to collective capabilities: The Capability Approach as a conceptual framework for self-help. Journal of Human Development, 7(3), 397-416.

Kean, H., \& Armstrong, P. (2020). A snapshot of COVID-19 related unemployment in South Africa. https://www.jdsupra.com/legalnews/a-snapshot-of-covid-19-related-90511/

Leßmann, O. (2012). Applying the Capability Approach empirically: An overview with special attention to labor. Management Revue, 23(2), 98-118. http://www.hamppejournals.de/hampp-verlag-services/get?file=/frei/mrev_2_2012_lessmann

Longshore Smith, M., \& Seward, C. (2009). The relational ontology of Amartya Sen's Capability Approach: Incorporating social and individual causes. Journal of Human Development and Capabilities, 10(2), 213-235. 
Lotz-Sisitka, H. (2019). Probing the potential of social ecosystemic skills approaches for green skills planning: Perspectives from expanded public works programme studies. In E. Rosenberg, H. Lotz-Sisitka \& P. Ramsarup (Eds.), Green Skills Research in South Africa: Models, Cases and Methods (pp. 113-127). Taylor \& Francis Group.

McGrath, S., Powell, L., Alla-Mensah, J., Hilal, R., \& Suart, R. (2020). New VET theories for new times: The critical capabilities approach to vocational education and training and its potential for theorising a transformed and transformational VET. Journal of Vocational Education \& Training, 6, 1-22.

McGrath, S. (2012). Building new approaches to thinking about vocational education and training and development: Policy, theory and evidence. International Journal of Educational Development, 32(5), 619-622. https://doi.org/10.1016/j.ijedudev.2012.04.003

Nussbaum, M. C. (2011). Creating capabilities: The human development approach. Harvard University Press.

Piketty, T. (2018). Capital in the twenty-first century. Harvard University Press.

Powell, L. (2012). Reimagining the purpose of VET - Expanding the capability to aspire in South African Further Education and Training students. International Journal of Educational Development, 32(5), 643-653. https://doi.org/10.1016/j.ijedudev.2012.01.008

Powell, L. (2020). Synthesis report on the Lived Livelihoods Study (Unpublished report). merSETA.

Powell, L., \& McGrath, S. (2014). Advancing life projects: South African students explain why they come to FET colleges. Journal of International and Comparative Education, 3(2), 213-226. http://dx.doi.org/10.14425/00.73.63

Powell, L., \& McGrath, S. (2019a). Skills for human development: Transforming Vocational Education and Training. Routledge Taylor and Francis Group.

Powell, L., \& McGrath, S. (2019b). Capability or employability: Orientating VET towards 'real work.' In S. McGrath, M. Mulder, J. Papier \& R. Suart (Eds.), Handbook of Vocational Education and Training: Developments in the changing world of work (pp. 369-392) Springer.

Rasool, H. (2016). Concept paper on setting up a skills measurement mechanism. FR Research Services. https://unevoc.unesco.org/e-forum/Conceptual Paper Skills Measurement_FR Research.pdf 
Reddy, V., Rogan, M., Mncwango, B., \& Chabane, S. (2018). Occupations in high demand in South Africa. Human Sciences Research Council

Press. http://hdl.handle.net/20.500.11910/13752

Robeyns, I. (2006). Three models of education: Rights, capabilities and human capital, Theory and Research in Education, 4(1), 69-84.

Sen, A. (1975). Employment, technology and development. Oxford University Press.

Sen, A. (1984). Resources, values and development. Basil Blackwell.

Sen, A. (1990). Justice: Means versus freedoms. Philosophy \& Public Affairs, 19(2), 111121.

Sen, A. (1992). Inequality reexamined. Oxford University Press.

Sen, A. (1993). Markets and freedoms: Achievements and limitations of the market mechanism in promoting individual freedoms. Oxford Economic Papers, 45(5), 19 541.

Sen, A. (1999). Development as freedom. Oxford University Press.

Sen, A. (2000). Social exclusion: concept, application, and scrutiny. Manilla.

Sen, A. (2009). The Idea of Justice. Penguin Books.

Spours, K. (2019a). Education/Employer partnership working and place-based skills development. Presentation at the Institute of Education, University College London. https://www.cityofglasgowcollege.ac.uk/sites/default/files/Ken Spours.pdf

Spours, K. (2019b). Social ecosystems: A place-based and inclusive approach to working, living and learning [Presentation]. Edge Foundation. https://discovery.ucl.ac.uk/id/eprint/10082167/

Spours, K. (2021). Social ecosystem thinking and the politics of transformation. https://www.kenspours.com/set-and-45-degree-politics

StatsSA. (2019). Quarterly Labour Force Survey, Quarter 2. http://www.statssa.gov.za/publications/P0211/P02112ndQuarter2019.pdf

Stewart, F. (2005). Groups and capabilities. Journal of Human Development, 6(2), 185-204.

Stiglitz, J. (2020). Conquering the great divide. https://www.imf.org/external/pubs/ft/fandd/2020/09/COVID19-and-global-inequalityjoseph-stiglitz.htm 
Szekely, E. (2019). A Political-economy orientation in TVET's project-based learning methodologies for sustainable development. In S. McGrath, M. Mulder, J. Papier \& R. Suart (Eds.), Handbook of Vocational Education and Training. Developments in the changing world of work (pp. 1-17). Springer.

Thurow, L. (1972). Education and economic equality. The Public Interest, 28(66), 66-81.

Unterhalter, E. (2013). Educating capabilities. Journal of Human Development and Capabilities, 14(1), 185-188.

Vally, S., \& Motala, E. (2014). Education, economy and society. UNISA.

Watts, M., Comim, F., \& Ridley, B. (2008, September). Adaptive preferences and educational policies. Paper presented at the Human Development and Capability Association Annual Conference. New Delhi.

Wedekind, V. (2014). Going around in circles: Employability, responsiveness and the reform of the college sector. In S. Vally \& I. Motala (Eds.), Education, economy and society (pp. 57-81) UNISA. 